\section{KAJIAN HUKUM PENERAPAN KONTRAK BAKU ELEKTRONIK PADA TRANSAKSI E-COMMERCE ${ }^{1}$ Oleh: Scivi Junifer Kapoh ${ }^{2}$ \\ Ronny A. Maramis ${ }^{3}$ Friend H. Anis ${ }^{4}$}

\section{ABSTRAK \\ Dalam Penelitian ini, tipe penelitian yang} dipakai oleh penulis adalah tipe penelitian hukum yuridis normative. Dengan data sekunder meliputi bahan hukum primer yaitu UUD 1945 KUH Perdata dan peraturanperaturan yang berkaitan dengan kontrak baku dan e-commerce, bahan hukum sekunder seperti jurnal hukum, buku literature. Teknik pengumpulan data dilakukan dengan cara mengumpul bahan hukum kepustakaan. Data yang diperoleh dari hasil penelitian dan pengumpulan data ini disusun secara sistematis dan logis. Dan kemudian data tersebut di analisa secara deskriptif kualitatif. Hasil penelitian ini menunjukan bahwa Khusus untuk pembuatan klausula baku pada transaksi e-commerce, pelaku usaha diwajibkan mengikuti prosedur yang ditentukan dalam UU Perlindungan Konsumen yang mencakup hak-hak dan kewajiban dari konsumen dan pelaku usaha. Sebagaimana ketentuan Pasal 48 ayat (2) Peraturan Pemerintah Nomor 82 Tahun 2012 Tentang Penyelenggaraan Sistem dan Transaksi Elektronik menyebutkan "kontrak elektronik yang dibuat dengan klausula baku harus sesuai dengan ketentuan mengenai klausula baku sebagaimana diatur dalam peraturan perundang-undangan. Demi upaya peningkatan perlindungan terhadap konsumen pemerintah membentuk Badan Penyelesaian Sengketa Konsumen (BPSK) dan Lembaga Perlindungan Konsumen Swadaya Masyarakat (LPKSM).

Kata Kunci: Kontrak Baku, Elektronik, Transaksi, E-Commerce

\footnotetext{
${ }^{1}$ Artikel Tesis.

${ }^{2}$ Mahasiswa pada Pascasarjana Unsrat, Manado. NIM. 18202108031

${ }^{3}$ Pascasarjana Unsrat, Doktor IImu Hukum

${ }^{4}$ Pascasarjana Unsrat, Doktor IImu Hukum
}

\section{PENDAHULUAN}

\section{A. Latar Belakang Masalah}

Perkembangan transaksi bisnis perdagangan secara elektronik (e-commerce), saat ini, volume transaksinya diprediksi akan dapat menyaingi volume perdagangan konvensional. ${ }^{5} \mathrm{Hal}$ ini tidak mengherankan jika kita lihat keuntungan dari e- commerce tersebut, seperti jangkauan pasar yang luas dan dapat menekan biaya operasional atau promosi (overhead) sebab perusahaan tidak harus membuka gerai (showroom) di berbagai tempat dan memasang iklan promosi di berbagai media untuk memperkenalkan produknya, cukup hanya dengan membuat homepage atau website saja yang berisi informasi perusahaan beserta produkproduknya. Industri e-commerce di Indonesia diharapkan mampu terus berkembang. Transaksi elektronik tidak hanya sekadar mendukung perekonomian negeri ini, tapi juga menjadi tulang punggung Indonesia di era digital ekonomi, melalui penambahan volume transaksi yang dilakukan.

Transaksi perdagangan secara elektronik seringkali dijumpai adanya kontrak atau perjanjian untuk melakukan transaksi jual beli produk yang ditawarkan melalui website atau situs internet milik perusahaan. Kontrak tersebut pada umumnya berbentuk kontrak elektronik (e-contract) yaitu kontrak atau perjanjian yang dibuat oleh pihak penjual/perusahaan melalui sistem elektronik, dimana para pihak tidak saling bertemu langsung.

Kontrak elektronik (e-contract) berbeda dengan kontrak biasa atau konvensional di dunia nyata (offline) yang umumnya dibuat di atas kertas dan disepakati para pihak secara langsung melalui suatu pertemuan atau tatap muka. Didalam pelaksanaan transaksi perdagangan elektronik (e-commerce), terdapat 2 (dua) cara penggunaannya melalui media internet yaitu, pertama melalui aplikasi Electronic Data Interchange (EDI) yang

\footnotetext{
${ }^{5}$ Harian Kompas. 2020. Volume Bisnis commerce di Indonesia Mencapai USD 130 Miliar.http://biz.kompas.com/read/2015/11/20/1015001 28/Tahun.2020.Volume.Bisnis.Ecommerce.di.Indonesia.Mencapai.USD.130.Miliar. Diakses tanggal 29 Januari 2020.
} 
digunakan untuk mentransfer dokumen secara elektronik seperti order pembelian, invoice, dokumen pengapalan dan korespondensi bisnis lainnya. EDI adalah cara mengganti transaksi melalui kertas ke dalam bentuk elektronik. $^{6}$

Perkembangan aturan-aturan perdagangan juga tidak terlepas dari pengaruh perkembangan teknologi. Dengan lahirnya $e$ commerce engaruh teknologi tersebut semakin nyata. Menurut hukum Perdata Indonesia Agar kontrak yang terjadi akibat transaksi dagang elektronik dapat dikatakan sah, maka kontrak tersebut juga harus memenuhi persyaratan sahnya perjanjian menurut Pasal 1320 KUH Perdata. Kontrak elektronik dibuat melalui sistem elektronik. Dimana sistem elektronik merupakan serangkaian perangkat dan prosedur elektronik yang berfungsi mempersiapkan, mengumpulkan, mengolah, menganalisis, menyimpan, menampilkan, mengumumkan, mengirimkan, dan/atau menyebarkan informasi elektronik. ${ }^{7}$ Informasi elektronik adalah salah satu atau sekumpulan data elektronik, termasuk tetapi tidak terbatas pada tulisan, suara, gambar, peta, rancangan, foto, electronic data interchange (EDI), surat elektronik (electronic mail), telegram, teleks, telecopy atau sejenisnya, huruf, tanda, angka, kode akses, simbol atau perforasi yang telah diolah yang memiliki arti atau dapat dipahami oleh orang yang mampu memahaminya.

Perbedaan secara fisik antara kontrak elektronik dengan kontrak konvesional, namun untuk kedua kontrak tersebut tetap tunduk pada aturan hukum kontrak atau hukum perjanjian atau hukum perikatan. Dimana pada kedua jenis kontrak tersebut juga harus memenuhi "syarat-syarat sah suatu perjanjian" dan "azas-azas perjanjian". ${ }^{8}$ Disamping itu, walaupun kontrak elektronik kebanyakan berbentuk kontrak standar (kontrak baku) yang sudah ditentukan oleh pihak penjual, kontrak standar tersebut tidak bisa melanggar Undang-Undang Nomor 8 Tahun 1999 tentang

\footnotetext{
${ }^{6}$ Kamlesh K. Bajaj \& Debjani Nag. 1999. E-commerce: The Cutting Age of Business. New Delhi: Tata Mcgraw-Hill Publishing Company Limited. 13-14.

${ }^{7}$ Cita Yustisia Serfiani, et.al. 2013. Buku Pintar Bisnis Online dan Transaksi Elektronik. Jakarta: Gramedia Pustaka Utama Jakarta. 99.

${ }^{8}$ Mieke Komar Kantaatmadja. 2001. Cyberlaw: Suatu Pengantar. Cetakan 1. Bandung: ELIPS Bandung. 15.
}

Perlindungan Konsumen. ${ }^{9}$ Dengan demikian kontrak elektronik juga harus memperhatikan kepentingan konsumen dalam pembuatan kontraknya, termasuk juga dalam penerimaan barang yang dibeli oleh konsumen harus sesuai.

Transaksi bisnis perdagangan secara elektronik (e-commerce) yang dilakukan dengan mediae-contract atau perjanjian elektronik yang dilakukan dalam transaksi bisnis era digital saat ini. Sesuai dengan kharakter standar bisnis yang efektif dan efisien, maka teknologi sangat perlu untuk diterapkan. Namun demikian masih banyak yang memiliki keraguan terkait dengan kekuatan hukum perjanjian elektronik ini, karena sifatnya yang tidak nyata secara fisik. Perdagangan secara elektronik merupakan bentuk perdagangan yang memiliki ciri khas tersendiri yaitu perdagangan yang melintasi daerah bahkan batas negara, tidak bertemunya penjual dan pembeli secara langsung, dilakukan dimana saja dan kapan saja, menggunakan media internet. Kondisi tersebut di satu sisi akan menguntungkan konsumen, karena mempunyai banyak pilihan untuk mendapatkan barang dan tidak perlu beranjak dari tempat tinggalnya akan tetapi di sisi lain pelanggaran akan hak-hak konsumen sangat riskan terjadi karena karakteristik $e$ commerce yang khas.

Pelanggaran terhadap hak-hak konsumen, seperti transaksi yang bentuknya digital, sehingga mudah diubah oleh penjual sehingga hal ini menimbulkan peluang bagi penjual untuk memperoleh keuntungan sepihak kepada para pembeli. Sebagai contoh, barang yang diterima pembeli tidak seperti yang ditampilkan pada tawaran produk di website yang dilihat oleh pembeli, mutu produk yang dikirim tidak sesuai harapan, barang terlambat datang/diterima, dll permasalahan yang harus dihadapi konsumen pada saat transaksi perdagangan elektronik telah dilakukan, padahal uang konsumen sebelumnya telah dibayarakan.

\footnotetext{
${ }^{9}$ Tami Rusli. 2012. Hukum Perjanjian yang Berkembang di Indonesia. Bandar Lampung: Anugrah Utama Raharja (Aura) Printing \& Publishing. 1.
} 


\section{B. Rumusan Masalah}

1. Bagaimanakah aspek hukum penerapan kontrak baku pada transaksi bisnis perdagangan elektronik (e-commerce)?

2. Bagaimanakah alternatif penyelesaian kontrak baku elektronik berdasarkan aturan undang-undang terhadap transaksi perdagangan elektronik (ecommerce)?

\section{Tujuan Penelitian}

Tujuan yang hendak dicapai dalam penelitian ini yakni :

1. Untuk memahami aspek hukum penerapan kontrak baku pada transaksi bisnis perdagangan elektronik (ecommerce).

2. Untuk memahami dan menganalisa tentang alternatif penyelesaian berdasarkan aturan undangundangterhadap transaksi perdagangan elektronik (e-commerce).

\section{METODE PENELITIAN}

\section{A. Jenis Penelitian}

Penelitian ini termasuk ke dalam jenis penelitian hukum yuridis normatif. Penelitian hukum normatif merupakan penelitian perpustakaan (library research). ${ }^{10}$ Nama lain dari penelitian hukum normatif adalah penelitian hukum doktriner, juga disebut sebagai penelitian perpustakaan atau studi dokumen. Disebut penelitian hukum doktriner, karena penelitian ini dilakukan atau ditujukan hanya pada peraturan-peraturan yang tertulis atau bahan-bahan hukum lainnya. ${ }^{11}$

Sebagai penelitian perpustakaan ataupun studi dokumen disebabkan penelitian ini lebih banyak dilakukan terhadap data yang bersifat sekunder yang ada diperpustakaan. Penelitian perpustakaan demikian dapat dikatakan pula sebagai lawan dari penelitian empiris (penelitian lapangan). Termasuk dalam data sekunder meliputi buku-buku, buku-buku harian, surat-surat pribadi dan dokumendokumen resmi dari pemerintah. ${ }^{12}$

\footnotetext{
${ }^{10}$ J. Supranto. 2003. Metode Penelitian Hukum dan Statistik. Jakarta: Rineka Cipta. 2.

${ }^{11}$ Bambang Waluyo. 2008. Penelitian Hukum Dalam Praktek. Jakarta: Sinar Grafika. 13.

12 Ibid.
}

Penelitian hukum normatif mencakup penelitian terhadap asas-asas hukum $:^{13}$

1. Asas kontrak sebagai hukum mengatur

2. Asas kebebasan berkontrak

3. Asas pacta sunt servanda

4. Asas konsensual

5. Asas obligator

\section{B. Sumber Data}

Penelitian ini menggunakan data sekunder. Sebagai sumber/bahan informasi yang terdiri dari bahan hukum primer, bahan hukum sekunder, dan bahan hukum tertier.

1. Bahan hukum primer, yaitu semua bahan atau materi hukum yang mempunyai kedudukan mengikat secara yuridis. Meliputi peraturan perundangundangan, yang berhubungan dengan masalah hukum yang diteliti.

2. Bahan hukum sekunder, yaitu semua bahan hukum yang memberikan penjelasan terhadap bahan hukum primer. Meliputi jurnal, buku-buku, referensi, hasil karya ilmiah para sarjana, hasil penelitian ilmiah yang mengulas mengenai masalah hukum yang diteliti dengan mengikutsertakan ilmu-ilmu sosial yang lain.

3. Bahan hukum tertier, yaitu semua bahan hukum yang memberikan petunjuk atau penjelasan terhadap bahan hukum primer dan sekunder. Meliputi bahan dari media internet, kamus dan sebagainya.

\section{Teknik Pengumpulan Data}

Teknik pengumpulan data dilakukan dengan cara mengumpul bahan hukum kepustakaan, wawancara dengan beberapa tenaga kerja permanen dan tenaga kerja kontrak sehingga memperoleh informasi dari pihak terkait, dan melakukan penelusuran melalui internet.

\section{Teknik Pengolahan Data}

Data yang diperoleh dari hasil penelitian dan pengumpulan data ini disusun secara sistematis dan logis guna mendapatkan gambaran luas dan jelas mengenai kajian

\footnotetext{
${ }^{13}$ Achmad Ichsan. Ibid. 15
} 
hukum penerapan kontrak baku elektronik pada transaksi e-commerce. ${ }^{14}$

\section{E. Analisis Data}

Berdasarkan menggunakan sifatnya, peneliti bertujuan untuk melukiskan tentang sesuatu fenomena atau peristiwa di suatu daerah dan pada saat tertentu, ${ }^{15}$ dengan menggunakan cara berpikir deduktif yaitu cara berpikir yang mendasar kepada hal-hal yang bersifat umum dan kemudian ditarik kesimpulan yang bersifat khusus sesuai dengan pokok permasalahan, analisis data dikerjakan melalui pendekatan kualitatif terhadap data sekunder. Kesimpulannya data yang diperoleh akan dianalisis secara deskriptif kualitatif. Analisis deskriptif kualitatif yaitu metode analisis data yang mengelompokkan dan menyeleksi data yang diperoleh dari penelitian lapangan menurut kualitas dan kebenarannya, kemudian dihubungkan dengan teori-teori, asas-asas, dan kaidah-kaidah hukum yang diperoleh dari studi kepustakaan sehingga diperoleh jawaban atas permasalahan yang dirumuskan. ${ }^{16}$

\section{HASILDANPEMBAHASAN}

\section{A. Aspek Hukum Penerapan Kontrak Baku Pada Transaksi Bisnis Perdagangan Elektronik (e-commerce)}

Kegiatan bisnis perdagangan secara elektronik (e-commerce) sering dijumpai adanya kontrak atau perjanjian untuk melakukan transaksi jual beli produk yang ditawarkan melalui website atau situs-situs internet. Kontrak tersebut pada umumnya berbentuk kontrak elektronik (e-contract) yaitu kontrak atau perjanjian yang dibuat oleh para pihak melalui sistem elektronik, dimana para pihak tidak saling bertemu langsung. Hal ini berbeda dengan kontrak biasa atau konvensional di dunia nyata (offline) yang

\footnotetext{
${ }^{14}$ Mukti Fajar dan Yulianto Achmad. 2007. Dualisme Penulisan Hukum. Yogyakarta : Fakultas Hukum Universitas Muhamadiyah Yogyakarta. 222.

${ }^{15}$ Bambang Waluyo. Op.Cit. 8.

16 Siti Nurwullan, Hendrik Fasco Siregar. 2019. Asas Konsensualisme Dalam Penambahan Klausula Kontrak Berdasarkan Prinsip Itikad Baik Prosiding Seminar Nasional. Enhancing Innovations for Sustainable Development : Dissemination of Unpam's Research Result. Volume 1 Nomor $1: 3$.
}

umumnya dibuat di atas kertas dan disepakati oleh para pihak secara langsung melalui tatap muka yang dilakukan.

Cita Yustisia Serfiani menyatakan bahwakontrak elektronik dibuat melalui sistem elektronik. ${ }^{17}$ "sistem elektronik" adalah serangkaian perangkat dan prosedur elektronik yang berfungsi mempersiapkan, mengumpulkan, mengolah, menganalisis, menyimpan, menampilkan, mengumumkan, mengirimkan, dan/atau menyebarkan informasi elektronik.

Informasi elektronik adalah salah satu atau sekumpulan data elektronik, termasuk tetapi tidak terbatas pada tulisan, suara, gambar, peta, rancangan, foto, electronic data interchange (EDI), surat elektronik (electronic mail), telegram, teleks, telecopy atau sejenisnya, huruf, tanda, angka, kode akses, simbol atau perforasi yang telah diolah yang memiliki arti atau dapat dipahami oleh orang yang mampu memahaminya.

Perkembangan aturan-aturan perdagangan juga tidak terlepas dari pengaruh perkembangan teknologi. Pengaruh teknologi tersebut semakin nyata dengan lahirnya $e$ commerce. Perkembangan yang cukup signifikan terjadi dengan melihat dari kuantitas transaksi melalui sarana e-commerce ini. Yahya Ahmad Zein menyatakan bahwa perkembangan sebuah teknologi pada era globalisasi memungkinkan suatu kegiatan perdagangan dapat dilakukan melalui media elektronik yang sering disebut dengan electronic commerce atau e-commerce. ${ }^{18} E$ commerce mulai berkembang secara signifikan ketika internet mulai diperkenalkan. Perkembangan internet ini mendorong transaksi-transaksi perdagangan internasional semakin cepat. Dengan internet, batas-batas wilayah negara dalam melakukan transaksi dagang menjadi tidak lagi signifikan. Praktik perdagangan melalui internet digambarkan juga sebagai final frontiers of commerce pada abad ke-21 saat ini. ${ }^{19}$

\footnotetext{
${ }^{17}$ Cita Yustisia Serfiani. Op.Cit. 99.

${ }^{18}$ Yahya Ahmad Zein. 2009. Kontrak Elektronik \& Penyelesaian Sengketa Bisnis E- Commerce. Bandung: Mandar Maju. 27-31.

19 http://news.liputan6.com/read/2221236/bisnispenjualan-online-kue-ganja-dibongkar. Diunduh 15 Agustus 2015.
} 
Di Indonesia sendiri terdapat beberapa contoh klasifikasi bisnis perdagangan elektronik (e-commerce) yaitu :

1. Listing/iklan baris

Seperti OLX, berniaga.com berfungsi sebagai platform dimana para individu bisa memasang barang jualan mereka secara gratis. Pendapatan diperoleh dari iklan premium. Pada jenis penjualan ini sangat cocok bagi penjual yang hanya ingin menjual barang dengan kuantitas kecil.

2. Online Marketplace

Seperti tokopedia.com, bukalapak.com, dimana website yang bersangkutan tidak hanya membantu mempromosikan barang dagangan saja, melainkan memfasilitasi transaksi uang secara online. Keseluruhan transaksi online sdifasilitasi oleh website yang bersangkutan

3. Shopping Mall

Misalnya blibli.com, zalora.com, Model bisnis hampir sama dengan marketplace, tetapi penjual yang dapat memasarkan barang disana hanyalah penjual atau brand ternama karena proses yang verifikasi ketat.

4. Toko Online

Seperti lazada.com, bhinneka.com. Pada bisnis ini sebuah toko online dengan alamat website sendiri dengan mana penjual memiliki stok produk dan menjualnya secara online kepada pembeli.

5. Toko online di media social

Pada jenis penjualan ini siapapun yang berjualan dengan media social dapat mempromosikan barang dagangan mereka dengan menggunakan situs media sosial seperti Facebook, Twitter dan Instagram.

6. Jenis-Jenis website crowd sourcing dan crowd funding

Pada website dipakai sebagai platform untuk mengumpulkan orang-orang dengan skill yang sama atau untuk penggalangan dana secara online. Misalnya kitabisa.com, wujudkan.com. ${ }^{20}$

Banyaknya kemudahan dalam mengakses internet membuat konsumen e-commerce meningkat, beberapa alasannya antara lain, adalah praktis, kemudahan sistem

\footnotetext{
${ }^{20}$ Mahir Pradana. 2015. Klasifikasi Jenis-Jenis Bisnis ECommerce di Indonesia. Jurnal Neo-bis. Volume 9 Nomor $2: 36$.
}

pembayaran, efisiensi waktu dan banyaknya harga promo yang menarik dari pelaku usaha online. Namun dibalik segala kemudahan dan keuntungan yang ditawarkan, timbul pula kekhawatiran akan tanggung jawab perusahaan online kepada konsumen $e$ commerce mengingat begitu banyaknya perusahaan online.

Bila dikaji secara hukum, maka sistem jual beli menggunakan media online tidak terlepas dari aspek hukum perjanjian yang mensyaratkan adanya suatu kata sepakat diantara pihak penjual dengan pembeli. Perjanjian tersebut diklasifikasikan sebagai perbuatan hukum ganda, dimana satu pihak atau lebih saling mengikatkan diri terhadap satu pihak atau lebih lainnya mengenai sesuatu hal, dan dianggap sah jika sudah memenuhi syarat-syarat sahnya suatu perjanjian sebagaimana diatur Pasal 1320 BW (Kitab Undang-Undang Hukum Perdata). ${ }^{21}$

Prinsip kebebasan berkontrak merupakan prinsip umum yang tidak bisa ditawar-tawar dalam setiap perjanjian, baik itu dalam perjanjian Islam. Perjanjian yang didalamnya terdapat unsur paksaan maka perjanjian tersebut dapat dibatalkan. ${ }^{22}$ Keberadaan prinsip ini diakui dalam KUHPerdata Pasal 1233 dinyatakan bahwa "tiap-tiap perikatan dilahirkan baik karena persetujuan, baik karena undang-undang". Pada ayat ini jelas bahwa setiap orang tidak dapat dipaksa oleh siapapun untuk melakukan perjanjian. Pada Pasal 1320 dijelaskan bahwa untuk sahnya suatu perjanjian diperlukan empat syarat :

1. Sepakat mereka yang mengikatkan dirinya;

2. Kecakapan untuk membuat suatu perikatan;

3. Suatu hal tertentu;

4. Suatu sebab yang halal. ${ }^{23}$

KUH Perdata dalam Pasal 1313 mengatur bahwa yang dimaksud dengan perjanjian adalah, "suatu perbuatan dengan mana satu orang atau lebih mengikatkan dirinya terhadap satu orang lain atau lebih." ${ }^{24}$ Sedangkan Soebekti

\footnotetext{
${ }^{21}$ Aloysius R. Entah. 2007. Klausula Eksonerasi Dalam Perjanjian Baku Pengangkutan Darat. Malang: Surya Pena Gemilang. 1.

${ }^{22}$ Abdul Karim Munthe. Op.Cit. 213.

${ }^{23}$ Ibid.

${ }^{24}$ Gemala Dewi, et.al. 2002. Hukum Perikatan Islam di Indonesia. Jakarta: Kencana. 45.
} 
memberikan definisi, bahwa perjanjian adalah : suatu peristiwa dimana seseorang berjanji untuk melaksanakan sesuatu hal. ${ }^{25}$

Berdasarkan definisi di atas penulis memberi defenisi bahwa yang dimaksud dengan perjanjian adalah suatu pernyataan yang dibuat oleh orang cakap hukum. Yang dimaksud dengan cakap hukum adalah mereka yang telah mencapai usia 21 tahun, tidak dalam pengampuan, dan istri, namun ketentuan istri tidak cakap hukum sudah tidak berlaku lagi sebab, dengan lahirnya UU No. 1 Tahun 1974 memberi derajat yang sama antara suami dan istri. Oleh karena itu istri dapat melakukan perbuatan hukum tanpa harus meminta izin dari suami. Selain itu orang dinyatakan pailit juga dikategorikan sebagai tidak cakap hukum (lihat Pasal 1330 KUHPerdata).

Transaksi-transaksi yang dilakukan, pada dasarnya para pihak baik penjual dan pembeli diberikan kebebasan untuk menentukan jenis, isi ataupun bentuk perjanjianyang di inginkan. Diberikannya kebebasan dalam membuat perjanjian yang dilakukan penjual dengan pembeli, dalam praktik sering timbul perjanjian yang mengandung syarat isinya membatasi tanggung jawab, menghapus tanggung jawab, membebaskan tanggung jawab, mengurangi tanggung jawab dan meringankan tanggung jawab salah satu pihak.

Ruang lingkup asas kebebasan berkontrak bisa kita lihat sebagai berikut :

1. Kebebasan untuk membuat atau tidak membuat perjanjian;

2. Kebebasan untuk memilih pihak dengan siapa ia membuat perjanjian;

3. Kebebasan untuk menentukan atau memilih causa dari perjanjian yang akan dibuatnya;

4. Kebebasan untuk menentukan objek perjanjian;

5. Kebebasan untuk menentukan bentuk suatu perjanjian; dan

6. Kebebasan untuk menerima atau menyimpangi ketentuan undang-undang yang bersifat opsional. ${ }^{26}$

Perlu diketahui bahwa walaupun sistem hukum nasional dan sistem hukum Islam mengakui akan kebebasan berkontrak, secara

\footnotetext{
${ }^{25}$ Subekti. 2002. Hukum Perjanjian. Cetakan ke-19. Jakarta: Intermasa. 1.

${ }^{26}$ Sutan Remy Sjahdeini. Op.Cit. 47.
}

hukum masih ada pembatasan yang harus diperhatikan. Dalam KUHPerdata pembatasan itu bisa kita lihat dari ketentuan Pasal 1320 yang membatasi subjek yang melakukan kontrak, serta isi kontrak yang tidak boleh bertentangan dengan norma dan hukum yang berlaku. Serta objek tersebut dijelaskan dalam Pasal 332 harus bernilai ekonomi. ${ }^{27}$

Klausula baku yang digunakan menjadi media untuk mempermudah transaksi jual beli yang dilakukan antara produsen dengan konsumen, yang ternyata sering disalahgunakan pihak produsen dengan memberikan persyaratan yang sangat merugikan bagi konsumen antara lain dalam perjanjian kredit perbankan, perjanjian asuransi, perjanjian penitipan barang, maupun perjanjian jula beli melalui e-commerce. Salah satu contoh bentuk klausula baku seperti: "barang yang sudah dibeli tidak dapat dikembalikan, barang rusak/hilang bukan menjadi tanggung jawab Penjual”.

\section{B. Alternatif Penyelesaian Berdasarkan Aturan Undang-Undang Terhadap Transaksi Perdagangan Elektronik (e- commerce)}

Berbicara tentang permasalahan hukum dari suatu kontrak, tidak terlepas dari keabsahan kontrak. Keabsahan suatu kontrak bergantung pada terpenuhinya syarat-syarat kontrak. Apabila syarat-syarat peSmbentukan kontrak telah terpenuhi, kontrak dapat dinyatakan sah. Namun, dalam konteks kontrak elektronik, permasalahan menjadi lebih rumit karena kontrak elektronik diantaranya dibentuk tanpa ada pertemuan langsung di antara para pihak dan tanpa menggunakan dokumen-dokumen berbasis kertas. Oleh karena itu, kemudian muncullah permasalahan tentang keabsahan dan keautentikan dokumen elektronik yang dipergunakan dalam membentuk kontrak elektronik. Permasalahan tersebut berkaitan erat dengan wujud dokumen dan tanda tangan elektronik yang cenderung untuk tidak tertulis langsung di atas kertas tetapi lebih bersifat abstrak (intangible). ${ }^{28}$

\footnotetext{
${ }^{27}$ Gemala Dewi. 2006. Aspek Hukum Dalam Perbankan dan Perasuransian di Indonesia. Edisi Revisi. Cetakan Ke-3. Jakarta: Kencana. 9.

${ }^{28}$ M. Arsyad Sanusi. Loc. Cit. 79.
} 
Tantangan lain mengenai perlindungan hukum terhadap konsumen adalah perkembangan e-commerce (transaksi elektronik) yang terus berkembang cepat seiring berkem bang nya teknologi telekomunikasi yang maju, sehingga peluang terjadinya sengketa akan menjadi sangat serius. ${ }^{29}$ Turban, Lee. mengemukakan bahwa mengingat perdagangan elektronik atau $e$ commerce merupakan sesuatu yang masih relatif baru, maka isu-isu hukum, etika dan isuisu kebijakan publik lainnya yang berkaitan dengan perdagangan elektronik pun masih terus berubah-ubah dan berkembang. ${ }^{30}$ Contoh isu-isu hukum dalam e-commerce itu antara lain masalah validitas kontrak, masalah kekayaan intelektual, dan pembajakan perangkat lunak. Hal ini menurut mereka, menunjukkan adanya celah-celah hukum baru yang harus dibenahi atau diperbaiki.

Mengenai hukum yang berlaku dan pengadilan yang berwenang yang akan digunakan, sering kali proses e-commerce melibatkan para pihak dari negara yang berbeda, sehingga dapat menjadi masalah adalah hukum mana di antara 2 (dua) negara tersebut yang berlaku jika ada persengketaan dan pengadilan mana yang berwenang. Hal ini penting diketahui mengingat tentang $e$ commerce ini, hukum dari negara yang satu berbeda dengan hukum dari negara yang lain. Yang jelas, setiap tindakan yang membawa akibat hukum, seperti kegiatan dalam hubungan dengan e-commerce ini haruslah ada hukum yang mengaturnya. Dalam hubungan dengan hukum mana yang berlaku dan pengadilan mana yang berwenang untuk kegiatan e-commerce ini, berlakulah prinsipprinsip hukum sebagai berikut :

1. Jika para pihak melakukan pilihan hukum (choice of law) dan atau pengadilan yang berwenang dalam kontraknya, maka

\footnotetext{
${ }^{29}$ Arfian Setiantoro, et.al. 2018. Jurnal Rechtsvinding. Urgensi Perlindungan Hukum Konsumen dan Penyelesaian Sengketa E-Commerce di Era Masyarakat Ekonomi Asean (The Urgency Of Consumer Law Protection and The E-Commerce Dispute Resolution In The Era Of Asean Economic Community). Volume 7 Nomor $1: 3$

${ }^{30}$ Efraim Turban, Jae Lee, et.al. 2000. Electronic Commerce: A Managerial Perspektif. New Jersey: Prentice Hall, Inc. 27.
}

hukum dan pengadilan yang dipilih tersebutlah yang berlaku.

2. Jika terhadap bidang e-commerce yang sudah terdapat perjanjian internasional dan di negara yang bersangkutan berlaku perjanjian internasional tersebut, maka ketentuan dalam perjanjian internasional tersebut haruslah dianggap berlaku.

3. Jika tidak ada pilihan hukum dan atau pengadilan, dan tidak ada pula perjanjian internasional, maka berlakulah prinsipprinsip hukum perdata internasional dari kedua negara tersebut.

Meskipun pengaturan tentang e-commerce ini jelas termasuk ke dalam lingkup bidang hukum bisnis, tetapi e-commerce juga banyak bersinggungan dengan cabang hukum lain. Cabang hukum lain yang banyak bersentuhan tersebut adalah sebagai berikut :

1. Hukum Komputer

2. Hukum Kontrak

3. Hukum Perlindungan Konsumen

4. Hukum Anti Monopoli dan Persaingan Curang

5. Hukum Pembuktian

6. Hukum tentang Telekomunikasi

7. Hukum Pajak

8. Hukum tentang Pembiayaan Via Kartu Kredit

Salah satu yang sangat menjadi masalah hukum tentang e-commerce adalah bahwa proses e-commerce belum dapat diakui sebagai bukti oleh alat bukti secara konvensional yang diakui oleh hukum pembuktian perdata seperti yang diatur dalam KUHPerdata dan Undang-Undang Hukum Acara Perdata maupun pembuktian pidana dalam Kitab Undang-undang Hukum Acara Pidana (KUHAP).

Beberapa prinsip hukum yang bersentuhan dengan e-commerce yang mestinya diakui sektor hukum pembuktian adalah sebagai berikut :

a. Semua informasi elektronik dalam bentuk data elektronik mestinya memiliki kekuatan hukum, sehingga mempunyai kekuatan pembuktian. Dengan demikian, data elektronik mestinya mempunyai kekuatan pembuktian yang sama dengan dokumen kertas.

a. Kontrak yang dibuat secara elektronik mempunyai akibat hukum dan kekuatan 
pembuktian yang sama dengan kontrak yang dibuat secara tertulis di atas kertas.

b. Tanda tangan elektronik semestinya mempunyai kekuatan pembuktian yang sama dengan tanda tangan biasa.

Akan tetapi, paling tidak terhadap kontrakkontrak penting, keharusan tertulis dan tanda tangan para pihak sampai kapan pun masih tetap diperlukan. Yang tergolong ke dalam kontrak penting tersebut adalah sebagai berikut : ${ }^{31}$

1. Kontrak pembelian benda tidak bergerak

2. Penerbitan surat berharga

3. Hibah

4. Wasiat

5. Surat kuasa

6. Dokumen kepemilikan

7. Jaminan hutang

8. Kontrak dalam hubungan hukum keluarga

Ada perkembangan di Indonesia dalam sistem hukum pembuktian khususnya yang menyangkut dengan pembuktian elektronik, setelah keluarnya Undang-Undang Nomor 11 Tahun 2008 tentang Informasi dan Transaksi Elektronik. Jika sebelumnya paling jauh bukti elektronik hanya dipakai dalam hukum acara perdata sebagai bukti "petunjuk", dengan keluarnya Undang-Undang Informasi dan Transaksi Elektronik tersebut, alat bukti elektronik berupa :

1. Informasi elektronik

2. Dokumen elektronik, dan

3. Hasil cetaknya.

Dengan tegas diakui sebagai alat bukti yang sah dan penuh di pengadilan asalkan memenuhi persyaratan-persyaratan tertentu sebagaimana yang ditentukan dalam undangundang. Dengan demikian, undang-undang ini diharapkan dapat menjawab berbagai hak yang berkenaan dengan dunia maya (cyber law, virtual morld law); hukum tentang teknologi informasi dan komunikasi (law of technology of information and communication), dan hukum tentang perdagangan dengan memakai elektronik (ecommerce).

Menurut UU ITE, maka yang dimaksud teknologi informasi adalah suatu teknik untuk mengumpulkan, menyiapkan, menyimpan, memproses, mengumumkan, menganalisis,

\footnotetext{
${ }^{31}$ Salim HS. 2006. Hukum Kontrak Teori, Teknik \& Penyusunan Kontrak. Jakarta: Sinar Grafika. 145.
}

dan menyebarkan informasi. Sedangkan yang dimaksud dengan sistem elektronik adalah serangkaian perangkat dan prosedur elektronik yang berfungsi mempersiapkan, mengumpulkan, mengolah, menganalisis, menyimpan, menampilkan, mengumumkan, mengirim, atau menyebarkan informasi elektronik. Selanjutnya, yang dimaksud dengan "informasi elektronik" adalah suatu atau sekumpulan data elektronik, termasuk tetapi tidak terbatas pada tulisan, suara, gambar, peta, rancangan, foto, electronic data interchange (EDI), surat elektronik (electronic mail), angka, kode akses, simbol atau perforasi yang telah diolah yang memiliki arti atau dapat dipahami oleh orang yang mampu memahaminya.

Transaksi elektronik adalah setiap perbuatan hukum yang dilakukan dengan menggunakan perangkat komputer, jaringan komputer, atau media elektronik lainnya. Sedangkan yang dimaksud dengan "dokumen elektronik" adalah setiap informasi elektronik yang dibuat, diteruskan, dikirimkan, diterima, atau disimpan dalam bentuk analog, digital, elektromagnetik, optical, atau yang sejenisnya, yang dapat dilihat, ditampilkan, dan/atau didengar melalui komputer atau sistem elektronik, termasuk tetapi tidak terbatas pada tulisan, suara, gambar, peta, rancangan, foto atau yang sejenisnya, huruf, tanda, angka, kode akses, simbol atau perforasi, yang memiliki makna atau arti dapat dipahami oleh orang yang mampu memahaminya.

Penggunaan alat bukti elektronik dalam sistem hukum pembuktian didasari atas asasasas sebagai berikut : ${ }^{32}$

1. Asas kepastian hukum

2. Asas manfaat

3. Asas kehati-hatian

4. Asas itikad baik, dan

5. Asas kebebasan memilih teknologi atau netral teknologi

Berikutnya, pengakuan hukum pembuktian terhadap penggunaan dan pemanfaatan alat bukti elektronik dari teknologi informasi dan transaksi elektronik di Indonesia adalah sebagai berikut :

\footnotetext{
32 Siswanto Sunarso. 2009. Hukum Informasi dan Transaksi Elektronik Studi Kasus Prita Mulyasari. Cetakan 1. Jakarta: Rineka Cipta. 78.
} 
1. Mencerdaskan kehidupan bangsa sebagai bagian dari masyarakat informasi dunia

2. Meningkatkan perdagangan dan perekonomian nasional melalui bisnis dengan menggunakan e-commerce.

3. Meningkatkan efektivitas dan efisiensi pelayanan publik

4. Memajukan pemikiran dan kemampuan masyarakat di bidang pemanfaatan teknologi informasi.

5. Memberikan rasa aman, keadilan, dan kepastian hukum bagi pengguna jasa teknologhi informasi.

Telah disebutkan bahwa alat bukti elektronik berupa informasi elektronik; dokumen elektronik; dan hasil cetaknya dengan tegas diakui sebagai alat bukti yang sah dan penuh di pengadilan, baik dalam proses peradilan perdata, peradilan pidana, maupun peradilan-peradilan lainnya. Dengan demikian, penggunaan alat bukti elektronik ini bahkan merupakan tambahan atau perluasan dari alat-alat bukti yang telah ada dan diakui oleh hukum acara perdata dan hukum acara pidana.

\section{PENUTUP}

\section{A. Kesimpulan}

1. Aspek hukum penerapan kontrak baku pada transaksi bisnis perdagangan elektronik (e-commerce) dengan melihat kontrak baku elektronik yang dibuat melalui sistem elektronik dengan menggunakan klausula baku sebagaimedia untuk mempermudah transaksi jual beli yang dilakukan antara produsen dengan konsumen. Selain mengacu pada adanya kesepakatan antara pihak penjual dengan pembeli, juga harus memenuhi syarat-syarat sebagaimana diatur Pasal 1320 BW (KUH Perdata). Kontrak baku juga diatur dalam UU. No. 8 Tahun 1999 tentang Perlindungan Konsumen dan UU No. 21 Tahun 2008 jo. UU No. 11 Tahun 2016 tentang Informasi dan Transaksi Elektronik (selanjutnya disebut UU ITE). Pembuatan klausula baku pada transaksi e-commerce di Indonesia, pelaku usaha diwajibkan mengikuti prosedur yang telah ditentukan dalam peraturan perundang-undanganya itu UUPK.

2. Permasalahan-permasalahan hukum yang terjadi dalam transaksi perdagangan elektronik (e-commerce) berawal dari pembeli yang merasa ditipu oleh toko online, karena barang yang diterima tidak sesuai pada gambar yang dimuat pada toko online. Oleh karena itu Pemerintah membentuk Badan Penyelesaian Sengketa Konsumen (BPSK) berdasarkan Pasal 49 ayat (1) UUPK serta Lembaga Perlindungan Konsumen Swadaya Masyarakat (LPKSM) berdasarkan Peraturan Pemerintah Republik Indonesia Nomor 59 Tahun 2001 Tentang Lembaga Perlindungan Konsumen Swadaya Masyarakat. Sebagai lembaga non struktural BPSK dan LPKSM hanya mampu menyelesaikan masalah yang dihadapi konsumen pada ranah sebelum masuk ke pengadilan/non litigasi cara melalui mediasi, arbitrase ataupun konsilidasi. Upaya perlindungan terhadap konsumen yang diberikan oleh BPSK yaitu perlindungan dalam bentuk tindakan preventif yakni perlindungan konsumen sebelum menderita kerugian yang ditimbulkan akibat mengonsumsi barang/jasa serta perlindungan represif yakni perlindungan konsumen setelah menderita kerugianyang ditimbulkan akibat mengonsumsi barang/jasa. Pembentukan BPSK dan LPKSM sebagai wadah bagi konsumen dan pelaku usaha untuk menyelesaikan permasalahan yang dihadapi serta memberikan perlindungan terhadap konsumen dapat dilihat Pasal 52 UUPK yang mengatur Tugas dan Wewenang BPSK dan Pasal 44 ayat (3) UUPK mengatur Tugas LPKSM. Dalam Pasal 44 UUPK hanya dapat memberikan memberikan advokasi terhadap konsumen sebatas pada wilayah di luar pengadilan, demikian halnya dengan ketentuan Pasal 49 UUPK hanya memberikan perlindungan hukum terhadap konsumen baik melalui mediasi, arbitrase maupun konsilidasi. 


\section{B. Saran}

1. Transaksi e-commerce perkembangannya sangat cepat di Indonesia, sehingga aturan hukumyang menjadi payung terhadap transaksi dan perlindungan konsumen seperti pada UUPK, senantiasa harus diuji dan ditinjau kembali serta dapat mengikuti aturan-aturan internasional terhadap transaksi. Demikian juga pengawasan yang tegas dalam setiap transaksi yang dilakukan, harus terus dilakukan. Pengawasan terhadap transaksi $e$ commerce tidak semudah bila melakukan pengawasan terhadap transaksi perdagangan konvensional, namun demikian Kementerian Perdagangan (Kemendag) selaku Pembina sektor perdagangan, dapat mewajibkan seluruh produk atau barang yang diperdagangkan melalui toko online (e-commerce) untuk memenuhi Standar Nasional Indonesia (SNI) dan kewajiban pencantuman label berbahasa Indonesia. Sehingga konsumen dapat secara mudah memahami syarat dan ketentuan transaksi yang dilakukan.

2. Pihak penjual dan pembeli pada transaksi e-commerce sebaiknya memahami bahwa kontrak elektronik dianggap sah apabila: Terjadi kesepakatan para pihak, dilakukan oleh subjek hukum yang cakap/berwenang mewakili sesuai dengan ketentuan peraturan perundang-undangan, Terdapat hal tertentu, dan objek transaksi tidak bertentangan dengan peraturan perundang-undangan, kesusilaan dan ketertiban umum. Pelaku usaha yang menawarkan produk melalui sistem elektronik juga wajib menyediakan informasi yang lengkap dan benar berkaitan dengan syarat kontrak, produsen dan produk yang ditawarkan.

\section{DAFTAR PUSTAKA}

Harian Kompas. 2020. Volume Bisnis commerce di Indonesia Mencapai USD
Miliar.http://biz.kompas.com/read/2 015/11/20/101500128/Tahun.2020.V olume.Bisnis.E-

commerce.di.Indonesia.Mencapai.US D.130.Miliar. Diakses tanggal 29 Januari 2020.

Kamlesh K. Bajaj \& Debjani Nag. 1999. Ecommerce: The Cutting Age of Business. New Delhi: Tata McgrawHill Publishing Company Limited..

Cita Yustisia Serfiani, et.al. 2013. Buku Pintar Bisnis Online dan Transaksi Elektronik. Jakarta: Gramedia Pustaka Utama Jakarta.

Mieke Komar Kantaatmadja. 2001. Cyberlaw: Suatu Pengantar. Cetakan 1. Bandung: ELIPS Bandung.

Tami Rusli. 2012. Hukum Perjanjian yang Berkembang di Indonesia. Bandar Lampung: Anugrah Utama Raharja (Aura) Printing \& Publishing.

J. Supranto. 2003. Metode Penelitian Hukum dan Statistik. Jakarta: Rineka Cipta.

Bambang Waluyo. 2008. Penelitian Hukum Dalam Praktek. Jakarta: Sinar Grafika.

Mukti Fajar dan Yulianto Achmad. 2007. Dualisme Penulisan Hukum. Yogyakarta : Fakultas Hukum Universitas Muhamadiyah Yogyakarta.

Siti Nurwullan, Hendrik Fasco Siregar. 2019. Asas Konsensualisme Dalam Penambahan Klausula Kontrak Berdasarkan Prinsip Itikad Baik Prosiding Seminar Nasional. Enhancing Innovations for Sustainable Development : Dissemination of Unpam's Research Result. Volume 1 Nomor $1: 3$.

Yahya Ahmad Zein. 2009. Kontrak Elektronik \& Penyelesaian Sengketa Bisnis ECommerce. Bandung: Mandar Maju.

Mahir Pradana. 2015. Klasifikasi Jenis-Jenis Bisnis E-Commerce di Indonesia. Jurnal Neo-bis. Volume 9 Nomor 2 : 36.

Aloysius R. Entah. 2007. Klausula Eksonerasi Dalam Perjanjian Baku Pengangkutan Darat. Malang: Surya Pena Gemilang.

Gemala Dewi, et.al. 2002. Hukum Perikatan Islam di Indonesia. Jakarta: Kencana. 
Subekti. 2002. Hukum Perjanjian. Cetakan ke19. Jakarta: Intermasa. 1.

Gemala Dewi. 2006. Aspek Hukum Dalam Perbankan dan Perasuransian di Indonesia. Edisi Revisi. Cetakan Ke-3. Jakarta: Kencana.

Arfian Setiantoro, et.al. 2018. Jurnal Rechtsvinding. Urgensi Perlindungan Hukum Konsumen dan Penyelesaian Sengketa E-Commerce di Era Masyarakat Ekonomi Asean (The Urgency Of Consumer Law Protection and The E-Commerce Dispute Resolution In The Era Of Asean Economic Community). Volume 7 Nomor $1: 3$

Efraim Turban, Jae Lee, et.al. 2000. Electronic Commerce: A Managerial Perspektif. New Jersey: Prentice Hall, Inc.

Salim HS. 2006. Hukum Kontrak Teori, Teknik \& Penyusunan Kontrak. Jakarta: Sinar Grafika..

Siswanto Sunarso. 2009. Hukum Informasi dan Transaksi Elektronik Studi Kasus Prita Mulyasari. Cetakan 1. Jakarta: Rineka Cipta. 